high in fibre, without excess caffeine containing drinks or alcohol, should keep the patient with true functional hypoglycaemia free of symptoms.

D J BETTERIDGE

Senior Lecturer in Medicine and Consultant Endocrinologist,

Rayne Institute,

University College London,

London WCIE 6JJ

1 Fischer KF, Lees JA, Newman JH. Hypoglycaemia in hospitalized patients, causes and outcome. N Engl f Med 1986;315:1245-50.

2 Malouf R, Brust JCM. Hypoglycaemia: causes, neurological manifestations and outcome. Ann Neurol 1985;17:421-30.

3 Marks V, Rose FC. Hypoglycaemia. 2nd ed. Oxford: Blackwell Scientific, 1981

3 Marks V, Rose FC. Hypoglycaemia. 2nd ed. Oxford: Blackwell

4 Service FJ. Hypoglycaemic disorders. Boston. G K Hall, 1983.

Nelson RL. Hypoglycaemia-fact or fiction. Mayo Clin Proc 1985;60:844-50.

Plum F. What causes infarction in ischaemic brain? The Robert Wartenberg lecture. Neurology 1983;33:222-33.

7 Yager J, Young RT. Non-hypoglycaemia is an epidemic condition. N Englf Med 1974;291:907-8.

8 Lev-ran A, Anderson RW. The diagnosis of post-prandial hypoglycaemia. Diabetes 1981;30: 996-9.

9 Charles MA, Hofeldt F, Shackelford A, et al. Comparison of oral glucose tolerance tests and mixed meals in patients with apparent idiopathic post-absorptive hypoglycaemia. Diabetes 1981;30: 465-70.

10 Hogan MJ, Service FJ, Sharbrough FW, Gerich JE. Oral glucose tolerance test compared with a mixed meal in the diagnosis of reactive hypoglycaemia. Mayo Clin Proc 1983;58:491-6.

11 Anderson RW, Lev-ran A. Hypoglycaemia: the standard and the fiction. Psychosomatics 1985;26:38-47.

12 Johnson DD, Dorr KE, Swenson WM, Service FJ. Reactive hypoglycaemia. FAMA 1980;243: $1151-5$.

13 Ford CV, Bray GA, Swerdloff RS. A psychiatric study of patients referred with a diagnosis of hypoglycaemia. Am f Psychiatry 1976;133:290-4.

14 Service FJ, Dale AJ, Elveback LR, Jiang N. Insulinoma: clinical and diagnostic features of 60 consecutive cases. Mayo Clin Proc 1976;51:417-29.

\section{Abuse of fresh frozen plasma}

Replacing the blood volume of a patient over 24 hours or less may lead to widespread bleeding because of defective coagulation. Stored blood contains virtually no functioning platelets, and factor V and factor VIII deteriorate during storage. ${ }^{1}$ A massive transfusion is therefore accompanied by dilution of these clotting factors, but bleeding after massive transfusion is more likely to be caused by consumption of clotting factors. ${ }^{2}$ Disseminated intravascular coagulopathy commonly follows trauma, sepsis, and hypotensionconditions that often necessitate a large transfusion. Because disordered blood coagulation may follow the transfusion of large volumes of stored blood it is often suggested that one or two units of fresh frozen plasma should be transfused routinely with every four units of stored blood. ${ }^{3}$ Yet nothing but anecdote supports this contention.

Many patients who receive a massive transfusion do not bleed abnormally, and one study showed that transfusing one unit of fresh frozen plasma for every three of whole blood or packed red cells did not reduce the amount of blood transfused. ${ }^{4}$ If abnormal bleeding does occur, thrombocytopenia, not deficiency of factor V or VIII, is the likeliest cause. ${ }^{5} \mathrm{~A}$ consensus development conference of the National Institutes of Health therefore recommended in 1985 that fresh frozen plasma should not be given as a supplement to blood transfusion unless an abnormality of blood coagulation was suspected on clinical grounds and had been confirmed in the laboratory. ${ }^{6}$

Fresh frozen plasma is often given as a volume expander, and an American study found that volume replacement was the sole indication for using half of the fresh frozen plasma supplied by one transfusion centre. ${ }^{7}$ The consensus conference advised that fresh frozen plasma should not be used for this purpose because safer, cheaper, and more readily available volume expanders exist.

Furthermore, the indiscriminate use of fresh frozen plasma is hazardous. Blood, or any of its unpasteurised derivatives, may transmit infection, including hepatitis and the acquired immune deficiency syndrome. Occasionally, the antibodies present in plasma may produce harmful effectsfor example, leucoagglutinins may cause pulmonary infiltrates. ${ }^{8}$ Anti-A and anti-B in plasma may destroy the recipient's red cells, although this hazard can be avoided by using fresh frozen plasma that is $\mathrm{ABO}$ compatible. Fresh frozen plasma may also cause hypersensitivity reactions. ${ }^{8}$ To take a wider view, any fresh plasma retained at a regional transfusion centre and supplied as fresh plasma to hospitals is withheld from the national Blood Products Laboratory. In north west London so much fresh frozen plasma is now called for by doctors that the transfusion centre cannot send its quota to the Blood Products Laboratory, which needs it to manufacture factor VIII and, coincidentally, albumin. Consuming fresh frozen plasma as an unnecessary adjunct to transfusion thus delays Britain's self sufficiency in factor VIII.

The proper indications for using fresh frozen plasma are few. The commonest indication is abnormal bleeding in which a clotting defect has been proved. This category includes some patients with established disseminated intravascular coagulopathy and some with liver disease who are either actively bleeding or about to undergo major surgery. ${ }^{9}$ Whether fresh frozen plasma or clotting factor concentrates should be given prophylactically to patients with liver disease before needle biopsy is debatable ${ }^{10}$; bleeding at biopsy seems to be unrelated to the prothrombin time. ${ }^{11}$ Anticoagulant action by compounds of the coumarin type may be reversed within 6-12 hours with vitamin $K$, but in more urgent circumstances fresh frozen plasma is required. Fresh frozen plasma may also be indicated in thrombotic thrombocytopenic purpura, although "outdated" plasma has been reported to be equally effective in this uncommon condition..$^{1213}$ Finally, fresh frozen plasma is required for patients with rare isolated factor deficiencies-of, for instance, factor $\mathrm{V}$ and factor $\mathrm{X}$-for which specific concentrates are unavailable.

Surgeons and anaesthetists are the greediest consumers of fresh frozen plasma, and often they are misusing it. They should restrict their demand for this scarce resource. ${ }^{14}$

Consultant in Charge,

JENNIFER JONES

Intensive Care Unit,

St Mary's Hospital,

London W2 INY

1 Slichter SJ, Counts RB, Henderson R, Harker LA. Preparation of cryoprecipitated factor VIII concentrates. Transfusion 1976;16:616-26.

2 Simmons RL, Collins JA, Heisterkamp CA, Mills DE, Andren R, Phillips LL. Coagulation disorders in combat casualties. Ann Surg 1969;169:455-82.

3 Wilson RF, Mammen EF, Walt AJ. Eight years of experience with massive blood transfusions. J Trauma 1971;11:275-85.

4 Mannucci PM, Federica AB, Serchia G. Hemostasis testing during massive blood replacement. A study of 172 cases. Vox Sang 1982;42:113-23.

5 Counts RB, Haisch C, Simon TL, Maxwell NC, Hermback DM, Carrico CJ. Hemostasis in massively transfused trauma patients. Ann Surg 1979;190:91-9.

6 National Institutes of Health Consensus Conference. Fresh-frozen plasma. Indications and risks. JAMA 1985;253:551-3.

7 Silbert JA, Bove JR, Dubin S, Bush WS. Patterns of fresh frozen plasma use. Conn Med 1981;45:507-11.

8 Mollison PL. Blood transfusion in clinical medicine. 7th ed. Oxford: Blackwell Scientific Publications, 1983.

9 Urbaniak SJ, Cash JD. Blood replacement therapy. BrMed Bulletin 1977;33:273-82.

10 Gazzard BG, Henderson IM, Williams R. The use of fresh frozen plasma or a concentrate of Factor IX as replacement therapy before liver biopsy. Gut 1975;16:621-25.

11 Ewe $\mathrm{K}$. Bleeding after liver biopsy does not correlate with indices of peripheral coagulation. Dig Dis Sci 1981;26:388-93.

12 Bymes JJ, Khurana $M$. Treatment of thrombotic thrombocytopenic purpura with plasma. $N$ Engl f Med 1977;297:1386-9.

13 Lian EC-Y, Harkness DR, Byrnes JJ, Wallach H, Nunez R. Presence of a platelet aggregating factor in the plasma of patients with thrombotic thrombocytopenic purpura and its inhibition by normal plasma. Blood 1979;53:333-8.

14 Oberman HA. Uses and abuses of fresh frozen plasma. In: Garretty G, ed. Current Concepts in transfusion therapy. Arlington VA: American Association of Blood Banks, 1985: 109-124. 